\title{
Çölyak Hastalığında Glutensiz Diyet Tedavisi: Bir Olgu Sunumu
}

\author{
Gluten Free Diet in Celiac Disease: A Case Report
}

\section{Yasemin Ertaş Öztürk ${ }^{1}$ Gizem Özata Uyar², Yeliz Serin³ ${ }^{3}$ Ödül Eğritaş Gürkan ${ }^{4}$}

Geliş tarihi/Received: 21.10.2018 • Kabul tarihi/Accepted: 20.11.2018

\section{ÖZET}

Çölyak hastalığı, genetik olarak yatkın bireylerde, gluten ve ilişkili proteinlerin alımıyla bağırsak mukozasının atrofiye uğramasına neden olan, immün aracılı kronik bağırsak hastalığıdır. Çölyak hastalığının tek tedavisi yaşam boyu katı glutensiz diyet uygulamaktır. Özellikle çocukluk döneminde tanı alan bireylerin, sağlıklı yaşıtları ile benzer büyüme ve gelişme sürecini sürdürebilmesi için diyete uyum şarttır. Glutensiz diyet tedavisinin diyetisyen kontrolünde sıkı bir şekilde izlenmesi diyete uyumu arttırarak kısa sürede serolojik ve klinik bulguların düzelmesini sağlayabilir. Bu yazıda çölyak hastalığı tanısı ile izlenen olguda, glutensiz beslenme tedavisinin önemi ve uygulaması tartışılmıştır.

Anahtar kelimeler: Çölyak hastalığl, glutensiz diyet tedavisi, çölyak serolojisi

\begin{abstract}
Celiac disease is an immune-mediated chronic bowel disease that causes atrophy of intestinal mucosa after consumption of gluten and related proteins in genetically predisposed individuals. The only treatment for celiac disease is the implementation of a life-long and strict gluten-free diet. Adaptation to the diet is essential to ensure that individuals who are especially diagnosed in childhood period are able to maintain a similar growth and development with their healthy peers. Strict gluten free diet which is supervised by a dietitian can lead to improve the adherence to diet and improve the clinical and serological findings in a short time. In this case report, the importance of gluten-free diet and adaptation of patient to the gluten-free diet were discussed.
\end{abstract}

Keywords: Celiac disease, gluten free diet treatment, celiac serology

\section{GİRIŞ}

Çölyak, genetik olarak yatkın bireylerde gluten ve ilişkili proteinlerin alımıyla bağırsak mukozasının atrofiye uğramasına neden olan, immün aracılı kronik bir bağırsak hastalığıdır. Farklı bölgelerden elde edilen verilere göre çölyak hastalığının prevalansı yaklaşık \%1 olup son zamanlarda belirgin bir artış

1. İletişim/Correspondence: Gazi Üniversitesi, Sağlık Bilimleri Fakültesi, Beslenme ve Diyetetik Bölümü, Ankara, Türkiye • E-posta: yasemnertas@gmail.com (ㄱ) https://orcid.org/0000-0002-8232-103X

2. Gazi Üniversitesi, Sağlık Bilimleri Fakültesi, Beslenme ve Diyetetik Bölümü, Ankara, Türkiye

그 https://orcid.org/0000-0002-9022-6956 göstermektedir (1). Türkiye'de 62 farklı şehrin dahil edildiği 6-17 yaş arasındaki okul çağı çocuklarında çölyak hastalığı prevalansı ise \%0.47 olarak bulunmuştur (2). Hastalığa bağlı olarak çocuklarda kronik diyare, büyüme-gelişme geriliği ve abdominal distansiyon ile karakterize klasik hastalık tablosu veya

3. Gazi Üniversitesi, Sağllk Bilimleri Fakültesi, Beslenme ve Diyetetik Bölümü, Ankara, Türkiye

(ㄱ) https://orcid.org/0000-0002-1524-0651

4. Gazi Üniversitesi, Çocuk Sağlığı ve Hastalıkları Anabilim Dalı, Gastroenteroloji ve Hematoloji Bilim Dalı, Ankara, Türkiye

(ㄱ) https://orcid.org/0000-0003-0230-7551 
intestinal belirtilere ek olarak gastrointestinal sistem belirtilerini içermeyen klasik olmayan bulgular da bulunabilir (1).

Çölyak patogenezinde genetik, çevresel ve immünolojik etmenler rol oynamaktadır. Çölyak hastalığının gelişiminden sorumlu genlerin insan lökosit antijenleri (HLA DQ2 ve HLA DQ8) ile güçlü bir bağlantısı vardır. Hastaların yaklaşık \%98'inin bu allelerden birini taşıdığı rapor edilmiştir (3). Çölyak hastalığının patogenezinde gluten içeren besinlerin tüketimi ile başlıca gliadin proteini lamina propriadaki doku transglutaminaz tarafından deamine edilir. Oluşan negatif yüklü moleküller antijen olarak sunulur ve T hücre aracılı sitokinlerin salınımı artar. Oluşan doku hasarı sonucunda da ince bağırsaklarda kript hiperplazisi, villus atrofisi ve lenfosit infiltrasyonu görülür. B hücrelerinden ise gliadin, doku-transglutaminaz ve endomisyal antikorları salınır (4). Avrupa Pediatrik, Gastroentroloji, Hepatoloji ve Beslenme [European Society for Paediatric Gastroenterology, Hepatology and Nutrition (ESPGHAN)] derneğinin kllavuzuna göre, özellikle çocuk yaş grubunda, çölyak hastalığı ile ilgili üç karakteristik belirti olması durumunda (klasik ince bağırsak semptomları, pozitif HLA DQ2 veya DQ8 varlığı ve immünglobulin A [IgA], doku transglutaminaz [tTG] düzeylerinin normalin 10 katı kadar olması) biyopsiye gerek olmadan çölyak tanısı konulabileceği rapor edilmiştir (1). Ancak, iyi ve doğru bir histolojik değerlendirme için mutlaka ince bağırsak biyopsisi yapılmalı ve Marsh sinıflaması ile tanı kesinleştirilmelidir (3).

Çölyak hastalığının tek tedavisi yaşam boyu katı bir glutensiz diyet uygulamaktır. Bu olgu sunumunda çölyak hastalığı tanısı ile izlenen olgunun tedavisinde tıbbi beslenme tedavisinin uygulanması ve önemi tartışılmıştır.

\section{OLGU SUNUMU}

Dokuz yaşında kız hasta bir yıldır devam eden karın ağrısı ve ishal şikayetleriyle Gazi Üniversitesi, Çocuk Gastroenteroloji Bilim Dalı’na başvurmuştur.
Bol sulu miktarda olan ishalin günde 4-5 kez olup, vücut ağırlığı kaybına neden olduğu öğrenilmiştir. Öz ve soy geçmişinde önemli bir özelliği olmayan hastanın fizik muayenesinde vücut ağırlığı $41.2 \mathrm{~kg}$ (85-95. persentil) ve boy uzunluğu $144 \mathrm{~cm}$ (85-95. persentil) olarak ölçülmüştür. Dışkının mikroskopik incelemesinde lökosit ve eritrosit izlenmemiş ve hastada parazit ya da mantara rastlanılmamıştır. Çölyak seroloji incelemesinde tTGIgA $>100 \mathrm{U} / \mathrm{mL}$, anti gliadin IgA= 129.6 U/mL ve serum IgA düzeyi 173 $\mathrm{mg} / \mathrm{dL}$ olarak ölçülmüştür. Endoskopisi, bulbus ve duedonum mukozasında çatlamış toprak manzarası ile uyumlu olarak izlenmiştir. Histopatolojik incelemede kriptlerde hiperplazi, yüzey epitelinde yoğun lenfositik infiltrasyon, lamina propriada yoğun mononükleer iltihabi hücre filtrasyonu ve eozinofil lökosit izlenmiş olup, Marsh Tip 3B ile uyumlu çölyak hastalığı olarak değerlendirilen hastanın eşlik eden otoimmun hastalıklar açısından (diabetes mellitus ve haşimato hastalığı) açlık kan şekeri normal, tiroid oto antikorları ise negatiftir. Tanı anında bakılan serum ferritin düzeyi $9 \mathrm{mg} / \mathrm{dL}$, folat düzeyi $8 \mathrm{ng} / \mathrm{mL}$ ve 25 hidroksi vitamin D düzeyi $13 \mathrm{mg} / \mathrm{dL}$ 'dir.

Çölyak hastalığı tanısı ile Gazi Üniversitesi, Sağlık Bilimleri Fakültesi, Beslenme ve Diyetetik Bölümü'ne yönlendirilen hastanın glutensiz diyet öncesi besin tüketim kaydı alınmış ve değerlendirilmiştir. Beslenme planı yapılırken, çölyaklı çocukların enerji ve besin ögesi gereksinmeleri sağlıklı yaşıtlarıyla aynı olduğundan hastanın cinsiyet, yaş ve fiziksel aktivite durumuna uygun tıbbi beslenme tedavisi Türkiye Beslenme Rehberi (TÜBER) 2015 (5) önerileri doğrultusunda hastanın beslenme alışkanlıkları da göz önünde bulundurularak planlanmıştır. Beslenme planı doğrultusunda hastanın ailesine ve kendisine glutensiz diyetin temel ilkeleri, çapraz kontaminasyon, etiket okuma, glutensiz ürünlere ulaşma, sosyal çevreye uyum vb. konularda eğitim verilmiştir. Hastanın glutensiz diyete uyumunun daha kolay olması açısından ilk ay her hafta, daha sonra ayda bir kez besin tüketim kayıtları alınmış ve değerlendirilmesi yapılmıştır. Hastanın glutensiz diyete başladığı ilk hafta içerisinde klinik 
şikayetlerinde azalmalar görülmüştür.

Glutensiz diyet tedavisinin ikinci ayından itibaren boy uzunluğunda artış saptanmıştır. Hastanın üçüncü ay kontrolünde serum ferritin ( $24 \mathrm{ng} / \mathrm{mL}$ ) ve folat (11 ng/ $\mathrm{mL}$ ) düzeylerinde iyileşmeler görülmüştür. Sıkı izlem süresince diyete uyumu oldukça iyi olan hastanın altıncı ay kontrolünde ise çölyak antikorları negatif (doku transglutaminaz IgA $<10 \mathrm{U} / \mathrm{mL}$ ve anti gliadin IgA $<30 \mathrm{U} / \mathrm{mL}$ ) bulunmuştur.

Hastanın izlem süresince vücut ağırlı̆̆ı (kg), boy uzunluğu $(\mathrm{cm})$, ilgili bazı biyokimyasal bulguları, planlanan glutensiz diyet programının örüntüsü ve izlem süresince besin tüketim kayıtlarının değerlendirilmesi Tablo 1'de verilmiştir.

Tablo 1. İzlem süresince hastanın vücut ağırlığı, boy uzunluğu, ilgili bazı biyokimyasal bulgular ve planlanan glutensiz diyet programının örüntüsü ile izlem süresince besin tüketim kayıtlarının değerlendirilmesi

\begin{tabular}{|c|c|c|c|c|c|c|c|c|}
\hline \multirow{2}{*}{ Değişkenler } & \multirow{2}{*}{$\begin{array}{c}\text { Normal } \\
\text { aralık }\end{array}$} & \multirow{2}{*}{ Tanı } & \multicolumn{6}{|c|}{ İzlem süresi } \\
\hline & & & 1. ay & 2. ay & 3. ay & 4. ay & 5. ay & 6. ay \\
\hline \multicolumn{9}{|l|}{ Antropometrik ölçümler } \\
\hline Boy uzunluğu (cm) & - & 144 & 144 & 145.5 & 145.5 & 145.5 & 146 & 147 \\
\hline Vücut ağırlığı (kg) & - & 41.2 & 41.2 & 39.4 & 41.5 & 41.8 & 41.1 & 41.3 \\
\hline \multicolumn{9}{|l|}{ Biyokimyasal bulgular } \\
\hline Immünglobulin A (IgA) (mg/dL) & $82-453$ & 173 & - & - & - & - & - & - \\
\hline Doku transglutaminaz IgA (U/mL) & $<10$ & $>100$ & - & - & - & - & - & $<10$ \\
\hline Anti gliadin IgA (U/mL) & $<30$ & 129.6 & - & - & - & - & - & $<30$ \\
\hline Hemoglobin (g/dL) & $10.6-13.2$ & 11.2 & - & - & - & - & - & - \\
\hline Ferritin (ng/mL) & $10.4-58.2$ & 9 & - & - & 24 & - & - & - \\
\hline Vitamin $\mathrm{B}_{12}(\mathrm{pg} / \mathrm{mL})$ & $201-1046$ & 377 & - & - & 321 & - & - & - \\
\hline Folat (ng/mL) & 12.2-23.6 & 8 & - & - & 11 & - & - & - \\
\hline 25 Hidroksi vitamin D $(\mu \mathrm{g} / \mathrm{L})$ & $30-100$ & 13 & - & - & 26 & - & - & - \\
\hline TSH (mIU/mL) & $0.77-5.64$ & 2.592 & - & - & - & - & - & 2.404 \\
\hline Serbest T4 (ng/dL) & $0.65-1.06$ & 0.81 & - & - & - & - & - & 1.08 \\
\hline \multicolumn{9}{|l|}{ Enerji ve besin ögeleri } \\
\hline Enerji (kkal/gün) & 1674 & 1897 & 1619 & 1289.2 & 1585.7 & 1361.8 & 1357.7 & 1499.5 \\
\hline Karbonhidrat (enerji \%) & 48.0 & 41 & 48.5 & 38 & 50 & 44 & 51 & 45 \\
\hline Protein (enerji \%) & 17.0 & 18 & 14.5 & 14 & 15 & 16 & 14 & 14 \\
\hline Yağ (enerji \%) & 35.0 & 41 & 37.0 & 48 & 35 & 39 & 36 & 41 \\
\hline Lif $(g)$ & 24.0 & 10.8 & 19.8 & 25.0 & 23.9 & 15.3 & 17.1 & 19.3 \\
\hline Kalsiyum (mg) & 1235.7 & 557.8 & 815.3 & 682.7 & 553.9 & 638.3 & 558.9 & 461.0 \\
\hline Demir (mg) & 10.5 & 11.5 & 11.0 & 10.1 & 13.2 & 8.6 & 8.4 & 8.2 \\
\hline
\end{tabular}

Enerji ve besin ögeleri başlğ̆ altında normal aralık başlı̆̆ altında belirtilen enerji ve besin ögeleri olgu için planlanan glutensiz diyetin örüntüsünü göstermektedir. Diğerleri hastanin glutensiz diyet öncesi (tanı sırasında) ve izlem süresince üç günlük besin tüketim kayıtlarının değerlendirmesidir. Olgunun birinci ay izlemindeki enerji ve besin ögeleri değerleri glutensiz diyete geçişinin ilk 4 haftasında alınan üçer günlük besin tüketim kayıtlarının ortalamasıdır.

\section{TARTIŞMA}

Çölyak hastalığı, ince bağırsak mukozasındaki yapısal proteinlere karşı lokal ve sistemik oto antijenlerin üretimi, bu nedenle de ince bağırsağın hücre-aracılı hasarı ile karakterize immünolojik bir bozukluktur (3). İnce bağırsaktaki hasara bağlı olarak çölyak hastalığında, demir yetersizliği anemisi, diyare veya konstipasyon gibi gastrointestinal sorunlar ve yorgunluk/bitkinlik semptomları sıklıkla gözlenmektedir (1). Bununla beraber, tanının geç konması durumunda çocuklarda büyümede duraksama ve gelişme geriliğinin yanı sıra, dental defektler, dermatitis herpetiformis, anksiyete, 
depresyon gibi nöropsikolojik bozukluklar görüldügü de rapor edilmiştir (1,3). Ayrıca, Tip 1 diyabet, otoimmün tiroid, Addison hastalığı gibi diğer otoimmün hastalıklar ve nedeni net olarak bilinmemekle birlikte Down sendromu, Turner sendromu ve Williams sendromu ile birlikteliği sık olduğundan bu hastalığa sahip bireylerin çölyak hastalığı yönünden taranması önemlidir (1). Tanı konulmamış olgularda osteoporoz, infertilite, daha düşük olasılıklarda da olsa non-Hodgkin's, Hodgkin's lenfoma ve ince bağırsak kanseri görülme riski bulunmaktadır (3). Hastalığın tedavisinde uygulanan glutensiz diyet çocukların intestinal semptomlarının remisyonunu sağlarken, aynı zamanda büyümeyi destekler ve kemik mineral yoğunluğunun korunmasını da sağlar. Glutensiz diyete uyumun arttırılmasında profesyonel sağlık personelinin gerekli izlemleri yapması önemlidir, çünkü diyete uyum \%40 gibi düşük düzeylerde olabilmektedir (1).

Günümüzde çölyak hastalığının bilinen tek ve etkin tedavisi glutensiz diyettir. Glutensiz diyetin temeli, diyetten buğday, arpa ve çavdar ile bu tahıllardan yapılan her türlü besini çıkarmaktır. Diyetin sıkı bir şekilde ömür boyu uygulanması gerekmektedir (6). Tolare edilebilen gluten dozuna yönelik kişisel farklılıklar olabileceği ve yalnızca 5-50 mg gibi oldukça düşük alımların çölyak hastalığında güvenilir kabul edilebildiğini gösterilmiştir (7). Bu durum diyette gluten ile kontamine olmuş besinlerin çok az miktarlarının bile ince bağırsağa zarar verebileceğine işaret etmektedir. Bu nedenle, kontaminasyon riskinin önemi ayrıntılı olarak aileye anlatılmış ve gerek besin seçiminde gerekse yiyecek hazırlama ve pişirme sırasında çapraz bulaşa dikkat edilmesi gerektiğini belirten broşür paylaşılmıştır.

Ülkemizde, Türk Gıda Kodeksi Gıda Etiketleme ve Tüketicileri Bilgilendirme Yönetmeliği (2017)’ne göre gluten içeren tahıllar (buğday, çavdar, arpa, yulaf) veya bunların melez türleri ve ürünlerinin besinlerin bileşeninde yer alması durumunda alerjen beyanı yapılması gereklidir, ancak besinin üzerinde "gluten içermez" ibaresinin beyanı isteğe bağlıdır
(8). Özellikle gluten içeren besinler birçok paketli üründe katkı maddesi olarak veya yapıyı oluşturmak amacıyla kullanılabildiğinden etiket okuma alışkanlığının kazandırılması son derece önemlidir. $\mathrm{Bu}$ vakada hem hastaya hem de ailesine beslenme eğitimi verilerek, etiket okuma örnekler üzerinden anlatılmıştır. Glutensiz özel ürünlerin çeşitliliği gün geçtikçe artmaktadır. Son ylllarda ülkemizde üretimi yapılan özel ürünlerin sayısında da artış görülmektedir. Bu ürünlere internet üzerinden veya büyük marketlerden ulaşllabilirken, çoğu market, kantin, kafeterya, kafe veya restoranlardan glutensiz ürün/yemeklere ulaşmak mümkün olamamaktadır. $\mathrm{Bu}$ konuda da ailelerin bilgilendirilmesi sağlanmıştır.

Glutensiz diyette elimine edilen tahıl ürünlerinin yerine çoğunlukla pirinç, mısır, patates ve bunların unları, nişastaları ile özel glutensiz unlar tercih edilmektedir. $\mathrm{Bu}$ besinler çoğunlukla glutenli muadillerine göre posa açısından fakirdirler. Öte yandan çocukların sıklıkla tüketmeyi tercih ettiği bisküviler, krakerler, kekler ve çikolatalarda ise yapının sağlanabilmesi için yağ içeriğinin arttırılması söz konusudur. Glutensiz diyetlerin birçoğunun besleyici doğru ürünler seçilmediği takdirde yeterli diyet kalitesine sahip olmadığı bildirilmiştir (9). Yapılan bir meta analizin sonuçlarına göre, iyi planlanmayan glutensiz diyetler posa, $B_{12}$ vitamini, folat, demir, çinko, magnezyum ve kalsiyumdan fakir, doymuş ve hidrojenize yağlardan ise zengin bulunmuştur (9). Bu durum hastalarda besin ögesi yetersizliklerinin devam etmesine ve obezite görülme riskinin artmasına neden olmaktadır. $\mathrm{Bu}$ olguda, hastanın genel beslenme durumu değerlendirilerek yaşına, cinsiyetine ve fiziksel aktivite düzeyine uygun enerji ihtiyacı göz önünde bulundurulmuş ve özellikle posa, demir, folat, $\mathrm{B}_{12}$ vitamini yönünden ihtiyacını karşılayacak bir beslenme düzeni oluşturulmuştur (Tablo 1). Ayrıca, glutensiz alternatif tahıl (karabuğday), pseudo-tahıl (amaranth, kinoa) ve tohum kaynaklarının (çiya) diyete eklenmesi teşvik edilmiştir. Böylece posa, demir, çinko ve kalsiyum yönünden glutensiz diyetin desteklenmesi sağlanmıştır. 
Çölyak hastalığında tanı alan hastalar çoğunlukla zayıf aralıkta iken, hafif şişman veya obez hastaların varlığı da dikkat çekmektedir. Diyetisyen tarafindan planlanan glutensiz diyetlerin büyüme geriliği olan çocuklarda olumlu etkisinin olduğu kadar hafif şişman çocuklarda vücut ağırlığının azaltılmasında etkili olabileceği gösterilmiştir (10). Bu olguda, vücut ağırlığı 85-95. persentilde olan olgunun yaşına ve besin ögesi gereksinmelerine göre planlanan glutensiz diyet ile vücut ağırlığında artışın önüne geçilmiş ve ilk hedef olarak serolojik bulguların düzelmesi sağlanmıştır.

Glutensiz diyet tedavisinin etkinliğinin izleminde hastaların transglutaminaz düzeylerinin düzenli aralıklarla ölçülmesi önerilmektedir. Bir yılın sonunda negatifleşmeyen serolojik bulguların varlığı diyette kontaminasyon olduğunu düşündürmelidir. Serolojik testlerin normale dönmesi mukozal iyileşmenin de göstergesi olarak kabul edilmektedir ve çölyak hastalığında serolojik bulguların normale dönme süresinin en erken 6. ayda çoğunlukla da birinci yılın sonunda olduğu bilinmektedir (1). Bu olguda glutensiz diyetin 6. ayında serolojik iyileşmeler görülmüştür ve mukozal iyileşmelerin göstergesi olarak ferritin ve folat düzeylerinde de düzelmeler olduğu gözlenmiştir (Tablo 1). Ayrıca D vitamini desteği yapılan hastanın serum D vitamini düzeylerinde de iyileşmeler olmuştur.

Özetle, glutensiz diyet tedavisinin diyetisyen kontrolünde sıkı bir şekilde izlenmesi diyete uyumun arttırılmasını ve kaçakların azalmasını sağlayarak 6 ay gibi kısa bir sürede serolojik ve klinik bulguların düzelmesini sağlayabilir. Bununla birlikte, çölyak hastalığının neden olduğu özellikle demir ve folat yetersizliklerinde de düzelmeler görülmesi sağlanır. Bu süre içerisinde her çocuğa özel olarak hastanın yaş ve cinsiyetine uygun planlanan bir diyet örüntüsü ile glutensiz diyetlerde çoğunlukla yüksek yağ ve düşük posa içeriğine sahip genel örüntünün değiştirilmesi ve böylece çocuğun normal büyüme ve gelişmesini destekleyecek yönde yeterli ve dengeli diyet alışkanlıklarının kazandırılması hedeflenmelidir. Olguların yalnızca büyüme geriliği şikayeti ile kliniğe başvurmayacağı, normal gelişim veya hafif şişman ya da obez hastaların da tanı alabileceği göz önünde bulundurulmalıdır. Her durumda, olguların diyetisyen kontrolünde düzenli boy ve vücut ağırlığı kontrolünün yapılması, hastanın doktor kontrolleriyle birlikte diyetinin de sorgulanarak değerlendirilmesi uyumu arttıracağından tercih edilmelidir.

Çıkar çatışması - Conflict of interest: Yazarlar çıkar çatışması olmadığını beyan ederler. - The authors declare that they have no conflict of interest.

\section{KAYNAKLAR}

1. Husby S, Koletzko S, Korponay-Szabo I, Mearin M, Phillips A, Shamir R, et al. European Society for Pediatric Gastroenterology, Hepatology, and Nutrition guidelines for the diagnosis of coeliac disease. J Pediatr Gastroenterol Nutr 2012;54:136-60.

2. Dalgic B, Sari S, Basturk B, Ensari A, Egritas O, Bukulmez A, et al. Prevalence of celiac disease in healthy Turkish school children. Am J Gastroenterol 2011;106:1512.

3. Macdonald S. Gastroenterology. In: Shaw V, Lawson M, editors. Clinical Paediatric Dietetics. 3rd ed. Oxford: Blackwell Publishing; 2007. p. 100-103.

4. Green PH, Cellier C. Celiac disease. N Engl J Med 2007;357:1731-43.

5. T.C. Sağlık Bakanlığı. Türkiye Beslenme Rehberi TÜBER 2015. Ankara, T.C. Sağlık Bakanlığı Yayın No:1031; 2016.

6. Niewinski MM. Advances in celiac disease and glutenfree diet. J Am Diet Assoc 2008;108:661-72.

7. Catassi C, Fabiani E, Iacono G, D'agate C, Francavilla R, Biagi F, et al. A prospective, double-blind, placebocontrolled trial to establish a safe gluten threshold for patients with celiac disease. Am J Clin Nutr 2007;85:1606.

8. Türk Gida Kodeksi Gida Etiketleme ve Tüketicileri Bilgilendirme Yönetmeliği, Resmi Gazete:26.01.2017-29960 2017. Erişim: http://www. resmigazete.gov.tr/eskiler/2017/01/20170126M1-6.htm Erişim tarihi: 14 Eylül 2018.

9. Vici G, Belli L, Biondi M, Polzonetti V. Gluten free diet and nutrient deficiencies: A review. Clin Nutr 2016;35:123641.

10. Reilly NR, Aguilar K, Hassid BG, Cheng J, DeFelice AR, Kazlow P, et al. Celiac disease in normal-weight and overweight children: clinical features and growth outcomes following a gluten-free diet. J Pediatr Gastroenterol Nutr 2011;53:528-31. 